はじめに

「岩石鉱物科学」は，鉱物科学およびこれに関連する諸分野の 学問の進歩と普及をはかることを目的として日本鉱物科学会が 発行する和文誌である。本誌の一般的投稿についての指針を 以下に規定する。本誌は国内誌である事に鑑み、編集委員長を はじめ、各編集委員は各種依頼原稿のとりまとめを積極的に 進めてもらう事が望まれる。また会員は解説原稿や新たな情報 が得られた場合、編集委員と意見交換をしたり、積極的に編集 事務局に原稿を送付したりする事が望まれる。

\section{I. 一般事項}

\section{1. 原稿の種類}

a. 原著論文 (Original article)（投稿原稿）

b. 短報 (Short note)（投稿原稿）

c. 総説 (Review) (依頼原稿)

d. 解説・資料(Short Review \& Scientific communication)

e. 鉱物の分析・解析のコツと勘どころ

(Key points for technical skills in analyzing minerals)

f. 最近の研究から(Recent advances)（依頼原稿）

（依頼及び投稿原稿）

g. 日本新産鉱物情報, その他

h. 討論 (Discussion)

i. 新刊紹介（Book Review）（依頼及び投稿原稿）

j. 学会記事・ニュース（News）（依頼及び投稿）

k. その他 編集委員会が掲載可能と認めたもの

\section{2. 執筆者}

原著論文・短報・討論の投稿は著者の中に学会会員が含まれ ている場合に限るが，他の種類の原稿はその限りではない。

\section{3. 投稿手続}

投稿原稿は電子メールによる添付ファイルでの投稿，または 従来の投稿方法を受け付けるので，「II. 投稿原稿」に従い投 稿原稿を作成し投稿すること。

(1) 電子メールによる投稿

a. 原稿送信先 : gkk_editorial@spa.nifty.com 送信メールのメッセージには, 原稿種類, タイトル, 著者名, 投稿者連絡先と共に投稿論文添付ファイル名を記載すること。

b. 投稿ファイル形態 :

本文：本文 (原稿種類, 和英タイトル, 著者名, 著者所属, 英 文アブストラクト, キーワード, 引用文献, 図 caption, 表タイトル，表脚注など含む) を Word で作成し，Word または PDFで提出する。

図：図番号，タイトル，説明を記載した各図を PDF， GIF， JPG，TIFのいずれかのファイルで提出する。 なお，図の画像は印刷上支障のないように鮮明な解像度で 作成すること。

表：表番号，タイトル，脚注を記載した各表を番号順に 1 つ のPDFにまとめて提出する。

(2) 従来の送付方法による投稿

a. 原稿送付先 :

厂980-8578 仙台市青葉区荒巻字青葉 6-3 東北大学理学部内 日本鉱物科学会 岩石鉱物科学 編集委員会 b. 送付方法

原稿 3 部（図表を含む，内 2 部はコピー）を上記宛に送る。 原稿送付と同時に電子メールで原稿種類, タイトル，著者名， アブストラクト，投稿者連絡先を編集委員会へ通知する。

\section{4. 文書と表のファイル形式}

本文は，Word，表は Word または Excel で作成する。

5. 査読とレフェリー

原著論文，短報は 2 名のレフェリーによる査読を行い，掲載 可否と修正の要不要を決定する。その他の原稿については最 低 1 名以上のレフェリーによる査読を行う。

\section{II. 投稿原稿}

\section{1。原稿の掲載頁制限}

原稿（図表含む）の本誌掲載頁を以下のように制限する。 但し, 本誌掲載 1 頁は全角約 2600 字。
a. 原著論 文：掲載頁18頁以内
b. 短 報 : 掲載頁 4頁以内
c. 総 説 : 掲載頁12頁以内
d. 解説 - 資料 : 掲載頁 8 頁以内
e. 討 論 : 掲載頁 2 頁以内
f. 新刊紹介: 掲載頁 1 頁以内
g. 学会記事・ニュース: 編集委員会が必要と認めた頁数

依頼原稿(会員, 非会員)については, 掲載頁制限は上記規定の 限りではない。

\section{2. 本文の作成}

本文は下記ページ設定に従い Word で作成する。
a. 余白：A4 判用紙 上下 $3 \mathrm{~cm}$, 左右 $2.5 \mathrm{~cm}$
b. 本文使用文字 : 日本語は明朝系 12 ポイント
c. 行間間隔 : 1.5 行 欧文は Times 系 12 ポイント
d. 本文ページには行番号とページ番号を付す。

\section{3. 本文の体裁}

以下本文の体裁は, 原則的に「原著論文, 短報, 総説, 解 説・資料, 鉱物の分析・解析のコツと勘どころ, 最近の研究 から，討論」に適用される。

a. 原稿の 1 頁目には原稿種類, タイトル, タイトルの英訳, 著 者名, 著者名のロ一マ字書きを付け, 脚注に著者の所属, 住 所とそれらの英訳，電子メールアドレスを明記する。

b. 原著論文, 短報, 総説, 解説 - 資料, 鉱物の分析 - 解析の コツと勘どころ, 最近の研究から, 討論」には必ず 300 語以 内の英文アブストラクトをつける。

c. 英文アブストラクトの下に英語でキーワードをつける（V. キーワードのつけ方 参照)。

d. 本文の 章一節一項一目は, I-1-(1)-a と段落番号を付す。

e. 本文は口語体とし, 新仮名遣いを用い, なるべく常用漢字を 使用する。

f. 数量をあらわす数字はアラビヤ数字とする。

g. 単位記号はなるべくSI 単位系を用いる(

h. イタリックで印刷すべき字句（ギリシャ文字，变数文字）は 
イタリックで記載する。

i. 本文中に外国語をはさむことはなるべくさける。適当な訳語 のない専門語は原綴りで表す。場合によってはカタカナ書き とする。

j. 固有名詞で読み誤るおそれのあるものには，ふりがな(ルビ) をつける。

\section{4. 表・図・写真の体裁}

(1) 表は以下に従って作成すること。

a. Word または Excel で作成する。

b. Table 1, 2, 3 ‥番号を付す。

c. 表中に使用する文字, 数字は Times 系, 9 ポイントの普通文 字を使用し, ギリシャ文字, 変数文字以外にはタリックとボ ールドを使用しない。

d. 讟線は数本の横線のみとして線の太さは 0.5 ポイント

e. 表は縮小して印刷はしないので本誌掲載誌面半頁から 1 頁以 内に作成すること。

f. 英文で作成した表のタイトルと脚注説明を各表に明記する。 さらに本文原稿引用文献の次の闌に Table 1, 2, 3・として記載 する。

(2) 図は以下に従って作成すること。

a. 高品位の鮮明な図を作成すること。

b. Fig. 1, 2, 3 ㄴ図の下に番号を付す。

c. グレースケールのグレー色濃淡, 図中の文字や記号の大きさ, 線の太さなど印刷時に縮小しても判読できるよう考慮して作 成すること。

d. 図の大きさは本誌掲載誌面半頁から 1 頁以内とする。

e. 写真は関連の複数写真を個別扱いはしないで, A4 判 1 頁に 見易くまとめ，各写真には a, b , c ・ ・を付し，他の図同様に 図番号を付す。

f. 英文で作成した図のタイトルと説明文を本文原稿引用文献の 次の欄に Fig. 1, 2, 3・として記載する

g. カラー写真を掲載希望の場合は，実費（1 頁当り約 5 6 万 円）を著者負担とする。依頼原稿や受賞者執筆の場合も負 担する。

\section{5. 引用文献}

（1）本文中の引用文献は姓（年）または（姓，年）とする。例え ば，「Robinson (1970)によれば,・・・」もしくは「・・・であ る（Robinson, 1970)。」など。

(2) 本文末尾にまとめられる引用文献は著者名のアルファベッ 卜順にならべ著者名（年）: 表題. 掲載誌, 巻, 頁. とし, 同一著者の同一年の 2 つ以上の文献を引用する場合は，a， b,・・・をつける。例えば, (1962a, 1962b)など。

(3) 以下の例にならう。

Deer, W.A., Howie, R.A. and Zussman, J. (1962) : Rockforming minerals, 1 . Ortho- and ring silicates. pp. 333, Longmans, London.

神津俶祐，益田峰一，上田潤一（1929）：方解石加熱に因 る軸率，面角及び容積の変化並びに其解離現象. 岩 鉱， 1, 1-15.

Davis,M.J. and Ihinger,P.D. (1998) : Heterogeneous crystal nucleation on bubbles in silicate melt. Amer. Mineral., 83,
1008-1015

久野 久（1954）：火山及び火山岩. pp. 255, 岩波書店, 東京.

（4）引用文献中での和文雑誌, 欧文雑誌などの省略は慣習に したがう。

\section{III. 受理原稿提出}

論文が受理されたら, 以下の指定ファイル形式で電子メール添 付または CD などで編集委員会宛へ提出すること。

(1) 本文 : Word ファイル

(2) 図 : PDF, GIF, JPG, TIFいずれかで作成されたファイル

(3) 表 : Word または Excel ファイル

\section{IV. 著作権}

本誌に掲載された論文等の著作権は，日本鉱物科学会にある。

V. キーワードのつけ方

著者がつけ，編集委員会が補う。

a . 英語で記載する。

b. 一般化した短い術語を用いる。

c. 数は 3 語以上, 10 語以下とする。

d. 原則として単数名詞を用いて, 前置詞の使用および形容詞形 の使用は避ける。

e. 以下の項目が含まれることが望ましい。対象物, 学問分野, 手法, データの種類, 作用, 機能, 現象, 概念, 地域, 地質 時代

f. 原則として, その重要度に従って配列し, 先頭に最も重要度 の高い語彙を置く。

\section{VI. 著者校正}

初校は著者に回すが，元の原稿を離れての文章修正は許されな い。また指定の期限までに返却されない時は, 編集委員会に校 正を一任したものとする。なお, 初校での図表の差替えや本文 ミスの訂正にかかる費用は著者の負担とする。

\section{VII. ページチャージ}

岩石鉱物科学は 2012 年 1 月 1 日以降に投稿された原稿からぺー ジチャージ制を導入する。著者は掲載 1 頁あたり 2,500 円のペー ジチャージを負担し別刷 50 部を受け取ることを基本として受理 された原稿を岩石鉱物科学へ掲載することができる。但し,

(1) 学生だけの著者で学振経費などの予算が無い場合はページ チャージの負担はなく, 20 部の無料別刷を受け取る。

（2）運営交付金, 科研費, 学振経費などのある一般の著者とそ の共著者, そして学振など予算のある上記(1)に該当しない 学生はページチャージを負担する。ページチャージには 50 部の別刷が含まれるが，それ以上希望の場合は実費負担と し, 別刷不要の場合は費用の割引は無い。

（3）運営交付金, 科研費, 学振経費などがない日本鉱物科学会 会員著者(退職した会員など)の場合，希望なら，ページチャ ージの負担なし，別刷もなしで掲載できるが，運営交付金， 科研費, 学振経費など持っている場合は，自動的に（3）は 適用されない。

非会員の依頼原稿や学会賞受賞者が執筆する研究紹介記事には ページチャージを適用しないで別刷 50 部を贈呈する。

ページチャージ額を示した別刷注文書を初校と共に著者に送付 するので, 必要事項を記入して初校と共に返送すること。 


\section{「岩 石 鉱 物 科 学」 編 集 規 則}

\section{原稿の受付および保管}

1.「岩石鉱物科学」の原稿執筆者は、原著論文・短報・討論の投 稿には原則として会員が著者に含まれている場合に限るが、 他の種類の原稿および編集委員会で承認された原稿はその限 りではない。

2. 原稿の投稿は電子メールによる添付ファイル、紙媒体での送 付も可能である。後者の場合は必ず原本とそのコピー2 部(計 3 部)を用意し、どちらの場合も投稿規程に定めるところに提 出する。

3. 原稿の書き方および投稿の手続きは別に定めた投稿規程によ る。

4. 編集委員会は提出された原稿の受付年月日を記録し, 原稿を 保管する。

5. 編集委員会は投稿規程に反する原稿については, これを受付 せず著者に投稿規程にそうよう修正を求めることができる。

6. 編集委員会は討論を内容とした原稿を受付したときは，それ を討論の対象となった論文の著者に提示し，なるべくその回答 の投稿を求める。

7. 編集委員会は会員および非会員に投稿を依頼することができ る。

8. 本会からの依頼によらないで, 非会員のみを著者とする原稿 が提出されたときは，その原稿は原則として受付されない。

9. 掲載が認められた最終原稿は原則として著者に返却しない。

\section{原稿の審査}

10. 編集委員長は原稿の種類を決定し、適任と思われる Associate Editor（以下担当編集委員）を選任し、查読に関す る手続きを依頼する。担当編集委員は複数の会員あるいは非 会員に原稿の查読を依頼し，查読者の判断にもとづき，その 原稿の種類を決定し(総説, 論説, 短報, 討論, 資料・解説な ど)、掲載の可否を審査する。

11. 担当編集者は掲載適当と認めた原稿について著者に修正を求 めることができる。

12. 担当編集者は掲載適当と認めた原稿に投稿規程に反する部分 があったときは，内容の本旨を変えない範囲で投稿規程に沿 うよう修正することができる。

13. 担当編集者は査読の結果に基づき、掲載不適当と認めた原稿 についてはその理由を付して著者に原稿を返却するとともに、 編集委員長に不受理の理由を通知寸る。

14. 掲載不適当と認められた原稿の著者はその理由を了解できな いとき, 編集委員会に再審査を申し出ることができる。この とき担当編集委員はその経緯を明らかにして編集委員会には かり, 編集委員会はその責任で当該原稿の採否を審査決定す る。

\section{論文の掲載}

15. 論文の掲載の順は原則として受理の順とする。ただし編集委 員会が必要と認めたときは変更されることがある。

16. 会費その他本会に納入すべき経費を滞納している会員の原稿 はそれが納入されるまで掲載を延期されることがある。

\section{校正}

17. 総説, 論説, 短報, 討論および解説・資料の初校校正は原則 として著者が行う。再校正以後は編集委員会の責任で行う。

18. 発行の時間的制約が著しいときは著者による初校校正を略し すべての校正を編集委員会の責任で行うことがある。

19. 校正のときに文章を書きかえることはできない。

\section{「岩石鉱物科学」の内容}

20. 広い意味で岩石学・鉱物学・鉱床学およびこれらに関連す るもの。

(1) 総説(Review): 研究論文, 学説などを独白の立場から総括し たもの。

(2) 論説(Original artic1e): 原著の研究論文で内容の主要な部分が 学術論文としてほかに印刷公表されて いないもの。

(3) 短報(Short note): 記載を主な内容とした短かい論文，または 新事実などの簡単な報告。

(4) 討論(Discussion): 本誌に掲載された論文についての学術的な 討論。

(5) 解説 - 資料(Short Review \& Scientific communication): 新しい学説などを紹介, 解説したもの。または いくつかの研究論文や学説などを単に紹介, 解 説したもの。

(6) 鉱物の分析・解析のコツと勘どころ

(Key points for technical skills in analyzing minerals)

(7) 最近の研究から(Recent advances)

（8）日本新産鉱物情報，その他

(9) 新刊紹介(Book review): 新しい文献(主に単行本など)の紹介

(10) ニュース(News)

(11) その他

21. 日本鉱物科学会記事(Announcement from the association): 本会 の事業運営等について報告, 記事など。

22. その他: 上にあげたもののほか，編集委員会が必要と認めた 事項。

\section{著作権}

23. 学会からの出版物に掲載された会員の論文等の著作権は, 日本鉱物科学会に帰属する。

本規則の変更は編集委員会の議決によるものとし，幹事会を 経て評議員会に報告されるものとする。 